\title{
Influence of Calcium, pH, and Moisture on Protein Matrix Structure and Functionality in Direct-Acidified Nonfat Mozzarella Cheese
}

\author{
D. J. McMahon, ${ }^{1}$ B. Paulson, ${ }^{1}$ and C. J. Oberg ${ }^{2}$ \\ ${ }^{1}$ Western Dairy Center, Department of Nutrition and Food Sciences, Utah State University, Logan, 84322 \\ ${ }^{2}$ Department of Microbiology, Weber State University, Ogden, UT 84408
}

\begin{abstract}
Influence of calcium, moisture, and $\mathrm{pH}$ on structure and functionality of direct-acid, nonfat Mozzarella cheese was studied. Acetic acid and citric acid were used to acidify milk to $\mathrm{pH} 5.8$ and 5.3 with the aim of producing cheeses with 70 and $66 \%$ moisture, and 0.6 and $0.3 \%$ calcium levels. Cheeses containing $0.3 \%$ calcium were softer and more adhesive than cheeses containing $0.6 \%$ calcium, and flowed further when heated. Cheeses with the same calcium content $(0.6 \%)$, the same moisture content, but set at different $\mathrm{pH}$ values (pH 5.3 and 5.8), exhibited no significant differences in melting or firmness. Increasing cheese moisture content from 66 to $70 \%$ produced a softer cheese but did not increase meltability. Such differences in functionality corresponded with differences in structure and arrangement of proteins in the cheese protein matrix. Microstructure of cheese with $0.6 \%$ calcium had an increase in protein folds and serum pockets compared with the $0.3 \%$ calcium cheeses that had a more homogeneous structure. Protein matrix in the low-calcium cheese appeared less dense indicating the proteins were more hydrated. In the $0.6 \%$ calcium cheeses, the proteins appeared more aggregated and had larger spaces between protein aggregates. Thus, between $\mathrm{pH} 5.3$ and 5.8 , calcium controls cheese functionality, and $\mathrm{pH}$ has only an indirect affect related to its influence on the calcium in cheese.
\end{abstract}

(Key words: nonfat Mozzarella, calcium, structure, $\mathrm{pH})$

Abbreviation key: $\mathbf{H P H}=$ high $\mathrm{pH}, \mathbf{L P H}=$ low $\mathrm{pH}$.

\section{INTRODUCTION}

When fat is removed from Mozzarella cheese, several undesirable characteristics develop including poor melt and shred fusion when cheese is cooked on a pizza,

Received May 13, 2005.

Accepted July 15, 2005.

Corresponding author: Donald J. McMahon; e-mail: djm@cc. usu.edu. as well as decreased stretch and increased hardness (Konstance and Holsinger, 1992; Mistry and Anderson, 1993; Tunick et al., 1993). Thus, lower fat cheeses often fail to meet consumer expectations for the cheese to melt and fuse properly, without excessive burning or blistering, when it is cooked on a pizza. These changes in melting properties can be related to an increase in protein interactions in lower fat cheeses, especially in nonfat cheese.

Typically, Mozzarella cheese has a fibrous appearance because of formation of protein fibers during the cooking and stretching process (Oberg et al., 1993). These fibers form because the fat globules in cheese physically hinder fusion of protein strands and are accumulated between the protein fibers. In nonfat cheese there is no such physical hindrance to fusion of protein strands and hence, no fiber formation is apparent (Paulson et al., 1998). The increased interactions between proteins thus requires more energy to allow the proteins to move past each other and cause the cheese to flow when heated.

Also of concern during cooking is excessive drying of the protein matrix before proper melting has occurred. Release of some fat onto the cheese surface helps prevent rapid evaporation and drying of the cheese shreds. If no fat is present in the cheese, the cheese shreds will quickly be dehydrated before melting can occur and will then brown and form dark blisters on the pizza (Rudan and Barbano, 1998). Thus, replacement of fat with water will not completely solve the functional issues of nonfat cheese, and a better understanding of how protein interactions within the cheese matrix affect cheese functionality is needed.

To accommodate additional water in the cheese without having excessive expressible serum, the water-holding capacity of the protein matrix needs to be increased. This can be achieved by using direct acidification for making a nonfat Mozzarella cheese because more calcium is lost during cheesemaking, which results in a cheese with a more hydrated protein matrix (Paulson et al., 1998; Guinee et al., 2002). Such directly acidified cheeses typically have higher moisture levels, calcium to protein ratios that are $30 \%$ lower, and increased melting properties compared to culture-acidified 
cheeses (Sheehan and Guinee, 2004). Breene et al. (1964) observed that direct-acid cheese made using calcium chelating acids, such as citric acid, had functional properties similar to cheeses with lower $\mathrm{pH}$.

It is recognized that the influence of calcium on protein-to-protein interactions within the matrix plays a significant role in cheese functionality (Paulson et al., 1998; Pastorino et al., 2003a,b; Joshi et al., 2003). A cheese with reduced calcium levels will be softer, have lower elastic and viscous moduli, increased meltability, and increased stretchability (Pastorino et al., 2003a; Joshi et al., 2004a,b). Calcium content accounts for 50\% or more of the variation in melting and flow properties of Mozzarella cheese (Joshi et al., 2004c).

Cheese $\mathrm{pH}$ influences cheese functional properties, but above $\mathrm{pH} 5.0$, this seems to be an indirect effect through its effect on calcium solubility. Injecting acid into cheese to lower $\mathrm{pH}$ increases the proportion of soluble calcium in the cheese. Between pH 5.35 and 5.0, such cheese becomes softer and has increased meltability (Pastorino et al., 2003b). Both of these changes are indicative of increased hydration of the protein network brought about by having less calcium bound to the caseins. Below $\mathrm{pH} 5.0$, loss of solubility of the caseins becomes the predominant factor influencing cheese functionality such that cheeses lose their ability to melt and stretch even though bound calcium continues to decrease (Ge et al., 2002; Pastorino et al., 2003b).

Sheehan and Guinee (2004) produced cheeses at $\mathrm{pH}$ 5.9 (by direct acidification) and $\mathrm{pH} 5.5$ (direct acidification and culture addition) and observed greater stretchability and flowability of the $\mathrm{pH} 5.5$ cheese even though both had similar calcium levels. However, because of adding culture, the $\mathrm{pH} 5.5$ cheese had higher protein breakdown during $70 \mathrm{~d}$ of aging. To determine if $\mathrm{pH}$ has an influence on cheese functionality independent of calcium, we designed an experiment using direct acidification to generate cheeses with varying $\mathrm{pH}$, moisture, and calcium levels to study their effect on cheese protein matrix and functionality.

\section{MATERIALS AND METHODS}

\section{Cheese Manufacture}

Skim milk was obtained from the Gary H. Richardson Dairy Products Laboratory (Utah State University, Logan), fortified with 1.0\% low-heat NDM, and pasteurized at $80^{\circ} \mathrm{C}$ for $29 \mathrm{~s}$ and cooled to $4^{\circ} \mathrm{C}$ overnight. The chilled milk, $10 \mathrm{~kg}$ per vat, was placed in 8 open rectangular vats, acidified, and treated using the milk treatments described in Table 1. Cheeses were made at a high $\mathrm{pH}$ (HPH) of 5.8 and a low $\mathrm{pH}(\mathbf{L P H})$ of 5.3, and at a high and low moisture level at each $\mathrm{pH}$ level. Modifications were also made to the cheese making with the aim of producing cheeses with high $(0.6 \%)$ and low $(0.3 \%)$ calcium levels at each $\mathrm{pH}$ and moisture combination.

Cheese vats were heated to $35^{\circ} \mathrm{C}$ in a jacketed water bath. Milk in each vat was set using $1.0 \mathrm{~mL}$ of singlestrength calf rennet (Rhodia, Inc., Madison, WI). After $15 \mathrm{~min}$, the curd was cut with 1.9 -cm knives, allowed to heal for $15 \mathrm{~min}$, and then stirred constantly for the times shown in Table 1. To aid in reducing calcium content, $15 \mathrm{~g}$ of EDTA was added to the whey during cheese making in 2 of the treatments. After whey draining, some treatments also were dry stirred to remove additional moisture. Curds were dry salted with $0.4 \mathrm{~g}$ of $\mathrm{NaCl}$ and hand stretched in $82^{\circ} \mathrm{C}$ water containing $5 \%(\mathrm{wt} / \mathrm{wt}) \mathrm{NaCl}$. Molten cheeses were stretched until smooth, and then placed in stainless steel molds $(9 \times 9$ $\times 9 \mathrm{~cm}$ ). The molded cheese was cooled in ice water for $1 \mathrm{~h}$, then vacuum packed, and stored at $4^{\circ} \mathrm{C}$.

\section{Cheese Composition}

Cheese was shredded in a hand-held electric shredder (Professional Salad Shooter, National Presto Industries, Inc., Eau Claire, WI) before analysis. All analyses were run on 14-d-old cheeses. Cheese moisture was determined in duplicate using a vacuum oven (method 926.08; AOAC, 1990). Protein was determined using the Kjeldahl method (method 920.123; AOAC, 1990). Calcium was determined using inductively coupled plasma atomic emission spectroscopy (EPA, 1992).

\section{Cheese Functionality}

Cheese melt was determined in duplicate by a modified melt-tube method using an oil bath at $90^{\circ} \mathrm{C}$ (McMahon et al., 1999). Overall melt was measured as distance traveled by the molten cheese after heating for $16 \mathrm{~min}$ (maximum distance was $220 \mathrm{~mm}$ ). Hardness, adhesiveness, gumminess, chewiness, and springiness of 14-dold cheese were measured in duplicate by texture profile analysis (van Vliet, 1991) using a two-bite $40 \%$ compression test on a texture analyzer (model 25 , Stevens Farnell, Dunmorow, UK).

\section{Electron Microscopy}

Samples for transmission and scanning electron microscopy were collected from 14-d-old cheeses from 2 replicates. All chemicals and supplies were obtained from Electron Microscopy Sciences (Fort Washington, PA). The cheeses were cut into slices $(1 \times 1 \times 5 \mathrm{~mm})$ and then fixed in $2 \%(\mathrm{wt} / \mathrm{vol})$ glutaraldehyde solution overnight. Samples for scanning electron microscopy were prepared according to the methods of McManus 
Table 1. Individual treatments applied per $10 \mathrm{~kg}$ of skim milk (fortified with $1.0 \% \mathrm{NDM}$ ) to manufacture high $\mathrm{pH}(\mathrm{HPH})$ and low $\mathrm{pH}(\mathrm{LPH})$ cheeses.

\begin{tabular}{|c|c|c|c|c|c|}
\hline Cheese & Milk treatment & $\begin{array}{l}\mathrm{pH} \\
\text { at set }\end{array}$ & $\begin{array}{l}\text { Whey } \\
\text { treatment }\end{array}$ & $\begin{array}{l}\text { Cut-to- } \\
\text { drain } \\
\text { time } \\
(\mathrm{min})\end{array}$ & $\begin{array}{l}\text { Dry } \\
\text { stirring } \\
\text { time } \\
(\mathrm{min})\end{array}$ \\
\hline HPH1 & $105 \mathrm{~mL}$ of acetic acid ${ }^{1}$ & 5.8 & - & 50 & 0 \\
\hline HPH2 & $105 \mathrm{~mL}$ of acetic acid & 5.8 & - & 50 & 40 \\
\hline НРН3 & $80 \mathrm{~mL}$ of acetic acid, $2.5 \mathrm{~g}$ of citric acid & 5.8 & EDTA $^{2}$ & 50 & 0 \\
\hline HPH4 & $80 \mathrm{~mL}$ of acetic acid, $2.5 \mathrm{~g}$ of citric acid & 5.8 & EDTA $^{2}$ & 50 & 40 \\
\hline LPH1 & $230 \mathrm{~mL}$ of acetic acid, $14 \mathrm{~g}$ of $\mathrm{CaCl}_{2}$ & 5.3 & - & 40 & 0 \\
\hline LPH2 & $230 \mathrm{~mL}$ of acetic acid, $14 \mathrm{~g}$ of $\mathrm{CaCl}_{2}$ & 5.3 & - & 40 & 30 \\
\hline LPH3 & $230 \mathrm{~mL}$ of acetic acid & 5.3 & - & 40 & 0 \\
\hline LPH4 & $230 \mathrm{~mL}$ of acetic acid & 5.3 & - & 40 & 30 \\
\hline
\end{tabular}

${ }^{1}$ Aqueous glacial acetic acid, $10 \%$ (vol/vol).

${ }^{2}$ Fifteen grams of EDTA added 15 min before whey drain.

et al. (1993). Samples for transmission electron microscopy were cut into cubes $(1 \times 1 \times 1 \mathrm{~mm})$ and placed in $1 \% \mathrm{OsO}_{4}$ in $0.2 \mathrm{M}$ cacodylate buffer for $1 \mathrm{~h}$, dehydrated in a graded ethanol series to $100 \%$ ethanol, then infiltrated with Spurr's epoxy overnight, transferred to BEEM capsules filled with Spurr's epoxy, and heated to $70^{\circ} \mathrm{C}$ for $24 \mathrm{~h}$. Thin sections $(70 \mathrm{~nm})$ were cut on an Ultracut ultramicrotome (Leica, Inc., Deerfield, IL), transferred to 300-hex mesh grids, and then counterstained with uranyl acetate and lead citrate. Sections were examined on a Zeiss 902 electron microscope (Carl Zeiss, Inc., Thornwood, NY) at an accelerating voltage of $80 \mathrm{kV}$.

\section{Experimental Design}

Five replicates of cheese were made using milk obtained on different days. Means were calculated from duplicate analyses and analyzed by Statistica (Statsoft Inc., Tulsa, OK) using the MANOVA function with 1 main effect of 8 treatments. When significant $(P \leq 0.05)$, differences between means were analyzed using least significant difference.

Table 2. Means for moisture, protein, and calcium content of directly acidified, nonfat Mozzarella cheese manufactured at high $\mathrm{pH}(\mathrm{HPH})$ and low $\mathrm{pH}(\mathrm{LPH})$ with treatments described in Table 1.

\begin{tabular}{|c|c|c|c|c|}
\hline Cheese & $\begin{array}{l}\text { Acidification } \\
\mathrm{pH}\end{array}$ & Moisture & Protein & Calcium \\
\hline & & & $-(\%)$ & \\
\hline HPH1 & 5.8 & $69.9^{\mathrm{bc}}$ & $23.6^{\mathrm{bc}}$ & $0.56^{\mathrm{b}}$ \\
\hline HPH2 & 5.8 & $65.7^{\mathrm{a}}$ & $27.4^{\mathrm{d}}$ & $0.63^{b c}$ \\
\hline HPH3 & 5.8 & $70.3^{c}$ & $23.0^{\mathrm{ab}}$ & $0.57^{\mathrm{b}}$ \\
\hline HPH4 & 5.8 & $66.0^{\mathrm{ab}}$ & $26.2^{\text {cd }}$ & $0.59^{b c}$ \\
\hline LPH1 & 5.3 & $70.3^{c}$ & $24.2^{\mathrm{bc}}$ & $0.56^{\mathrm{b}}$ \\
\hline LPH2 & 5.3 & $65.9^{\mathrm{ab}}$ & $27.4^{\mathrm{d}}$ & $0.67^{\mathrm{c}}$ \\
\hline LPH3 & 5.3 & $73.1^{\mathrm{d}}$ & $20.4^{\mathrm{a}}$ & $0.30^{\mathrm{a}}$ \\
\hline LPH4 & 5.3 & $67.9^{b}$ & $23.0^{\mathrm{ab}}$ & $0.34^{\mathrm{a}}$ \\
\hline
\end{tabular}

a,b,c,d Means with the same letter superscript within the same column were not significantly different.

\section{RESULTS}

\section{Cheese Composition}

Cheese composition is shown in Table 2. Fortification of cheese milk with $14 \mathrm{~g}$ of $\mathrm{CaCl}_{2}$ in the low $\mathrm{pH}$ cheeses (LPH1 and LPH2) increased calcium content in the finished cheese to $0.6 \%$ and was the same as the $\mathrm{pH}$ 5.8 cheeses. This is similar to the level of calcium found in commercially manufactured low moisture, part-skim Mozzarella cheese (USDA, 1980).

Acidification of cheese milk to $\mathrm{pH} 5.3$ without calcium fortification produced cheese with a lower $(0.3 \%)$ calcium content. Addition of citric acid in the manufacture of direct-acid cheese and the use of EDTA during cooking of high $\mathrm{pH}$ cheeses (HPH3 and HPH4) did not decrease calcium levels in the finished cheese as proposed. Cheese moisture increased as calcium was reduced from 0.6 to $0.3 \%$ in the LPH3 and LPH4 cheeses.

\section{Cheese Meltability}

The only factor that influenced meltability was calcium content. The LPH3 and LPH4 cheeses that contained $0.3 \% \mathrm{Ca}$, flowed the entire length of the melt tube $(220 \mathrm{~mm})$, whereas all other cheeses flowed only about 60 to $70 \mathrm{~mm}$ (Figure 1). Cheese melt was similar in all cheeses when the calcium content was $0.6 \%$, with no differences observed because of $\mathrm{pH}$ (HPH1 and HPH2 vs. LPH1 and LPH2) or moisture (HPH1 vs. HPH2, HPH3 vs. HPH4, LPH1 vs. LPH2, and LPH3 vs. LPH4).

\section{Cheese Texture}

Hardness of the nonfat cheeses depended on moisture content and calcium content (Figure 2). Cheeses containing $0.6 \%$ calcium were firmer than the low-calcium cheese; in each pair of treatments, increasing the moisture content $(\sim 5 \%)$ produced a softer cheese. Together, 


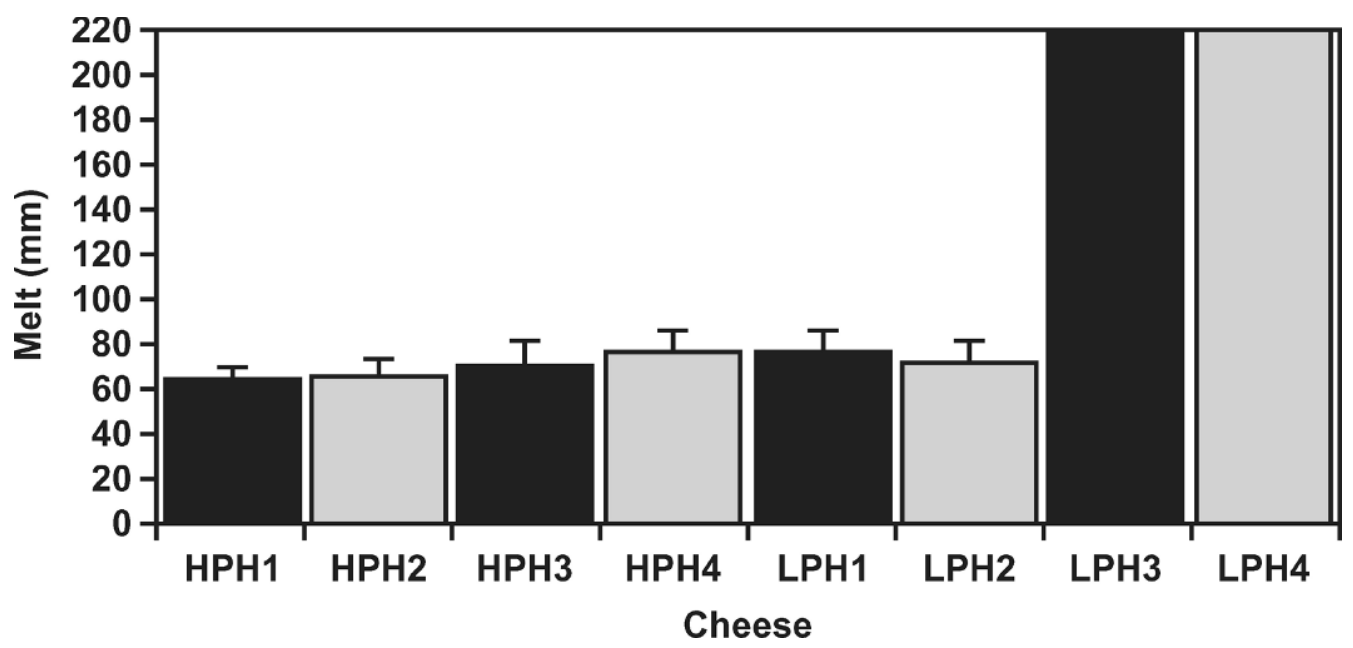

Figure 1. Mean cheese melt measurements of directly acidified, nonfat Mozzarella. Bars with matching colors represent cheeses that received similar moisture treatments during manufacture. Cheeses HPH1, HPH2, HPH3, HPH4, LPH1, and LPH2 have similar calcium (0.6\%); cheeses LPH 3 and LPH4 have lower calcium (0.3\%). Bars indicate SEM.

reducing calcium (to $0.3 \%$ ) and increasing moisture (to $73 \%)$ produced a nonfat cheese (LPH3) with very soft texture.

Nonfat cheeses with the typical calcium content of $0.6 \%$ had low adhesiveness (Figure 3 ), whereas the lowcalcium cheeses had a sticky texture as shown by high adhesiveness values. Moisture did not appear to influence the adhesiveness of the cheese matrix when calcium was $0.6 \%$, but increasing the moisture doubled the adhesiveness in the low-calcium cheese.

\section{Cheese Microstructure}

Similar microstructure was observed in scanning electron micrographs for all the nonfat cheeses with $0.6 \%$ calcium (Figure 4 ). When fractured surfaces were observed, these cheeses had numerous protein folds and serum pockets. This heterogeneous structure of the protein matrix in cheeses containing $0.6 \%$ calcium was evident at both $\mathrm{pH} 5.8$ (HPH1 and HPH2) and at $\mathrm{pH} 5.3$ (LPH1). In comparison, the cheese with $0.3 \%$ calcium

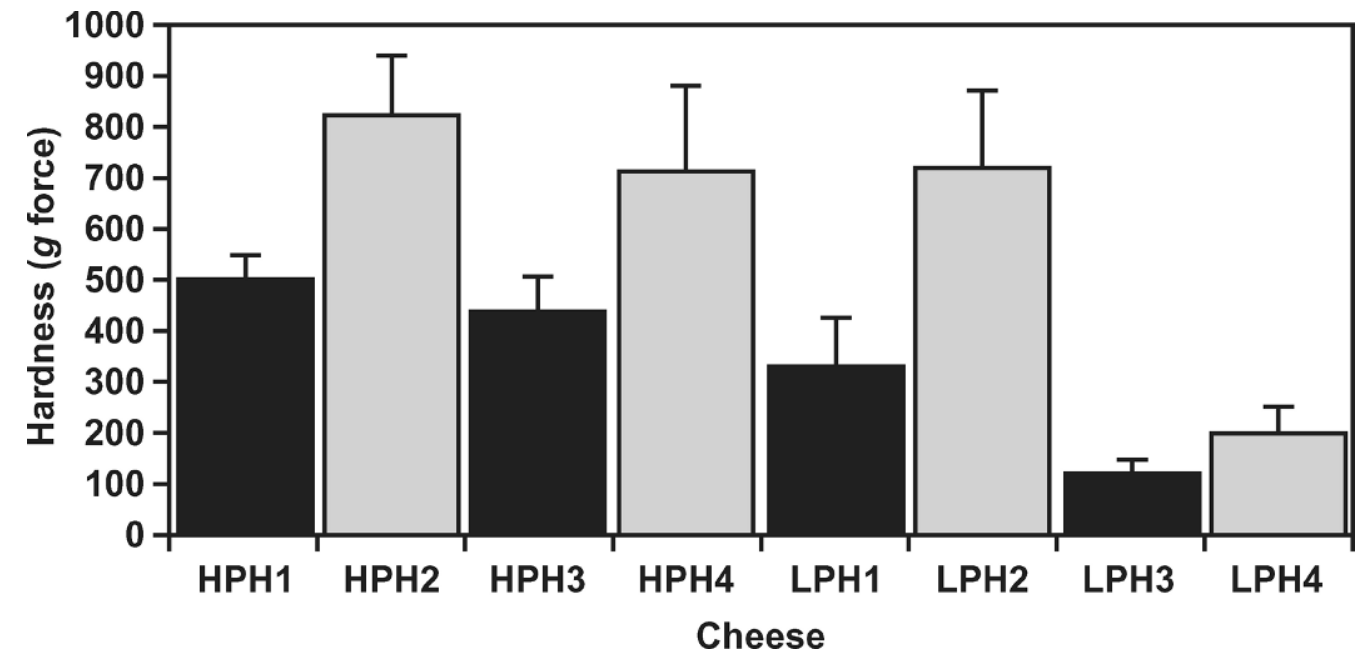

Figure 2. Mean cheese hardness measurements of directly acidified, nonfat Mozzarella cheese. Bars with matching colors represent cheeses that received similar moisture treatments during manufacture. Cheeses HPH1 through LPH2 have similar calcium level (0.6\%); cheeses LPH3 and LPH4 have lower calcium (0.3\%). Bars indicate SEM. 


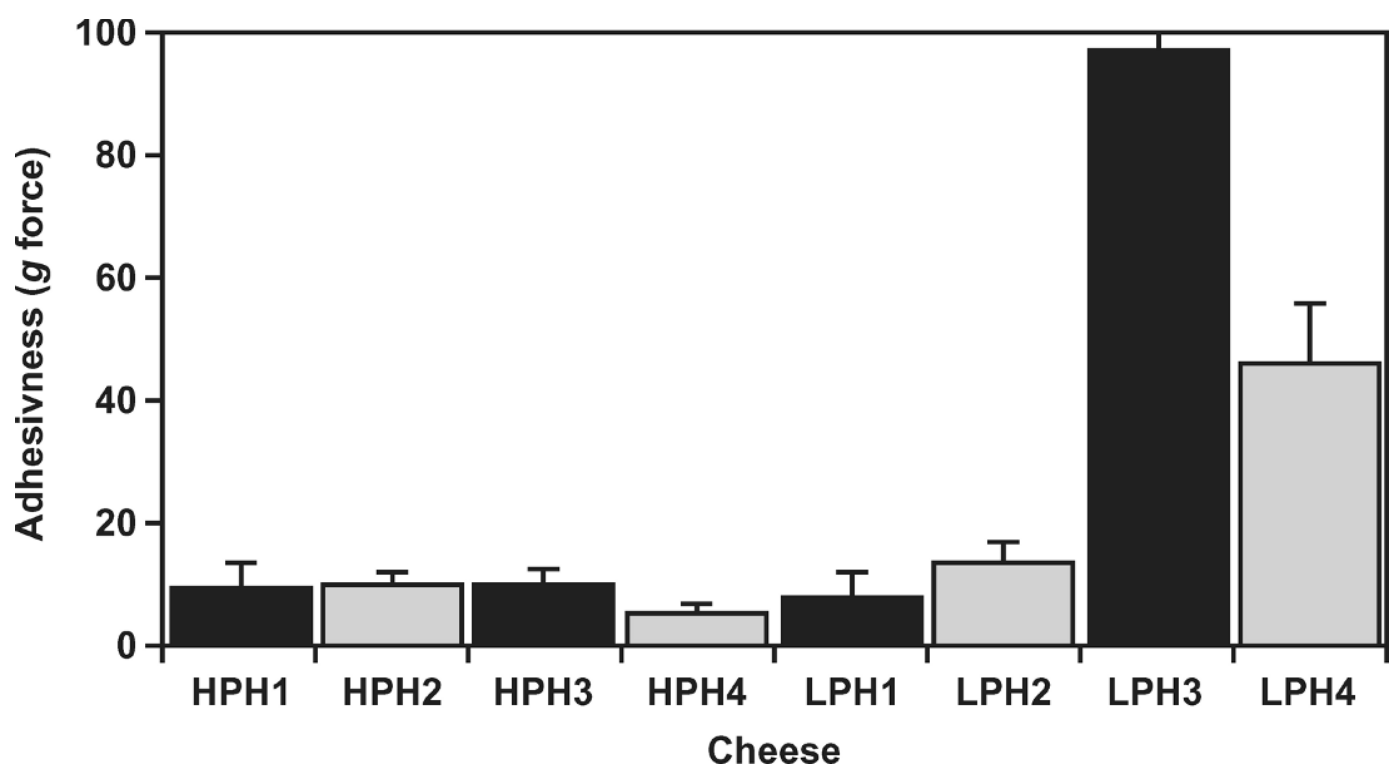

Figure 3. Mean cheese adhesiveness measurement of directly acidified, nonfat Mozzarella cheese. Bars with matching colors represent cheeses that received similar moisture treatments during manufacture. Cheeses HPH1 through LPH2 have similar calcium level (0.6\%); cheeses LPH3 and LPH4 have lower calcium (0.3\%). Bars indicate SEM.
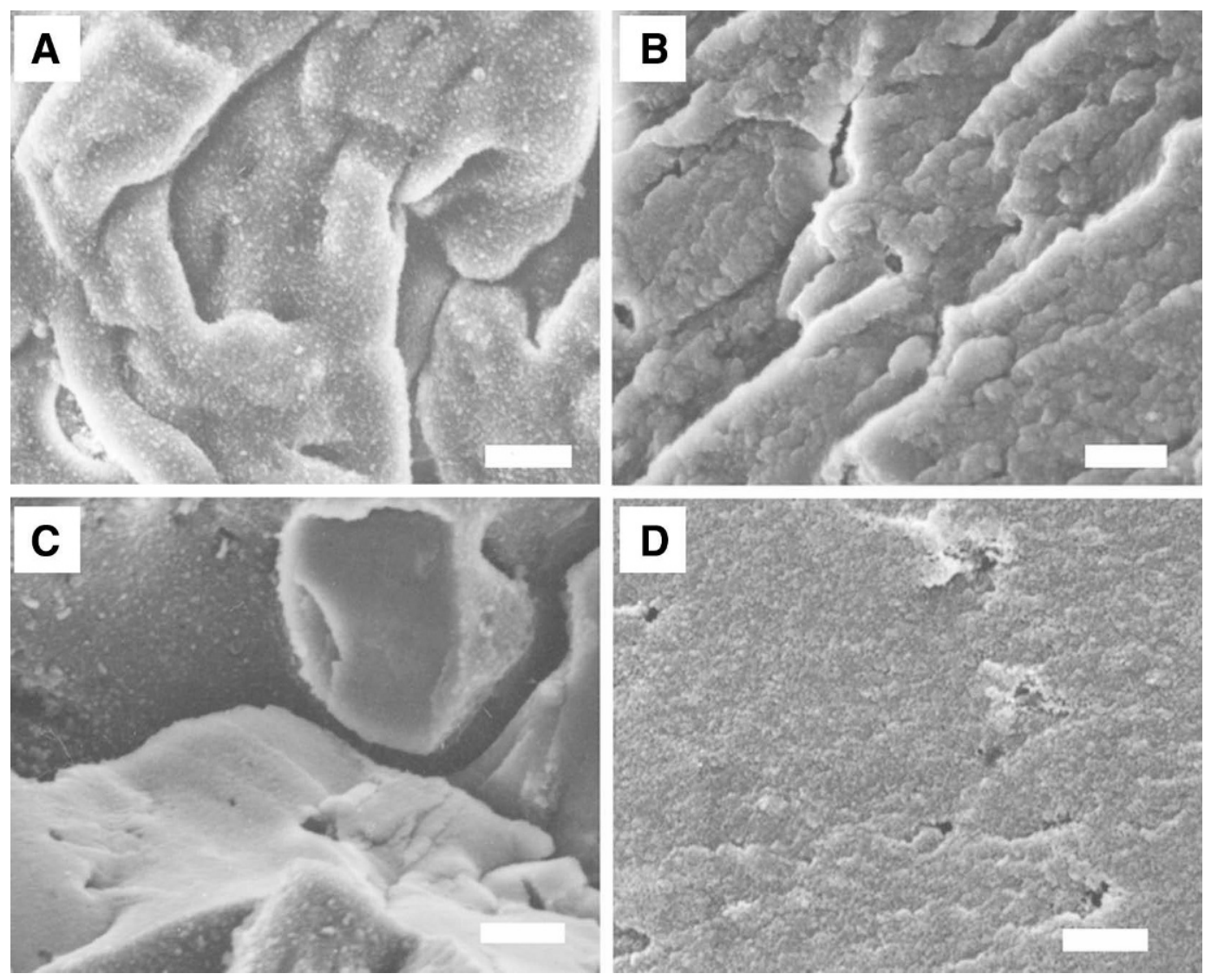

Figure 4. Scanning electron micrographs of pH 5.8 cheeses HPH1 (A) and HPH3 (B), and pH 5.3 cheeses LPH1 (C) and LPH4 (D); these cheeses contained $0.6 \%$ calcium $(\mathrm{A}, \mathrm{B}$, and $\mathrm{C}$ ) or $0.3 \%$ calcium $(\mathrm{D})$. Bar $=1 \mu \mathrm{m}$. 

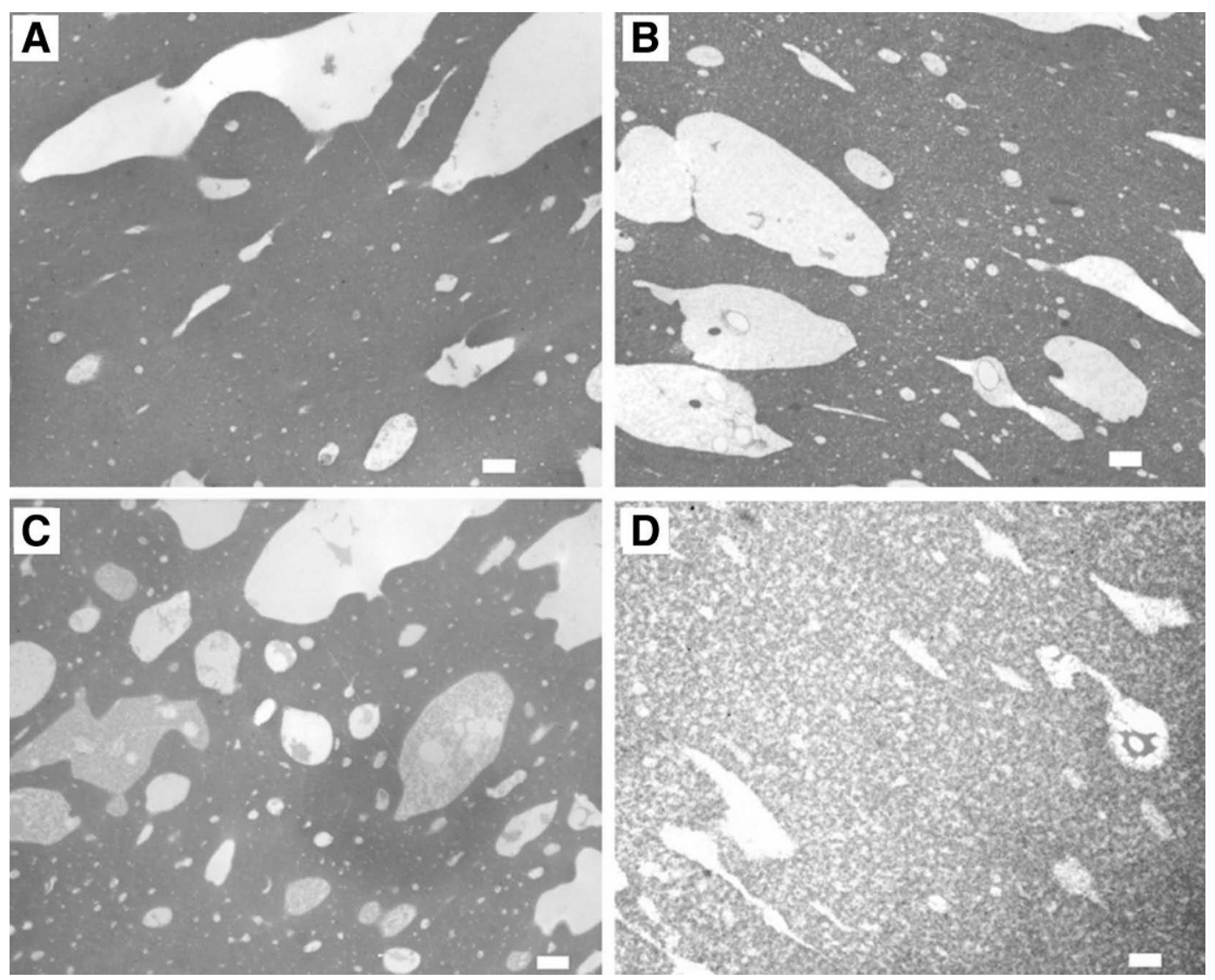

Figure 5. Low magnification transmission electron micrographs of $\mathrm{pH} 5.8$ cheeses HPH2 (A) and HPH4 (B) and pH 5.3 cheeses LPH2 (C) and LPH4 (D); these cheeses contained $0.6 \%$ calcium (A, B, and C) or $0.3 \%$ calcium (D). Bar $=1 \mu \mathrm{m}$.

(LPH3) had a much more homogeneous structure with no visible folds or pockets.

Similar differences in protein matrix structure were also observed when thin sections of cheese were examined using transmission electron microscopy (Figure 5). The cheeses containing $0.6 \%$ calcium and with moisture contents of $66 \%$ (HPH2, HPH4, and LPH2) had numerous serum pockets dispersed throughout a densely stained protein network structure. The cheese containing only $0.3 \%$ calcium (LPH4) exhibited a more open protein network structure (as shown by the lower electron density) with few serum pockets, even though it had higher moisture content $(68.5 \%)$ than the other cheeses (65.7 to $66.0 \%$ moisture). When the protein matrix areas of the cheeses were examined at higher magnification (Figure 6), the proteins in the higher calcium cheese were observed to be in a more aggregated state with larger spacing between the protein aggregates, than were the proteins in the low-calcium cheeses.

At each of the $\mathrm{pH}$-calcium treatment combinations, there was cheese made at 2 moisture levels. Lower moisture contents were obtained by dry stirring the curd after the whey was drained (as described in Table 2 ). The only difference observed in micrographs of such pairs of cheeses was that less fusion between protein strands was observed in the cheeses with the shorter make times and higher moisture (Figure 7A) than in cheese that was dry stirred to expel more whey during cheese making (Figure 7B).

\section{DISCUSSION}

\section{Calcium Interactions}

Cheeses with similar calcium levels had similar microstructure, texture, and meltability. At the calcium level typical in cheese manufactured using cultures (i.e., $0.6 \%$ ), the fractured surface of the cheese showed protein fibers and numerous serum pockets. This indicates that the presence of calcium led to strong proteinprotein interactions within the cheese matrix and, via syneresis, led to an exclusion of moisture from the cheese matrix during cheese making.

Conversely, at $0.3 \%$ calcium, the protein matrix was observed to be more homogeneous with very few serum 

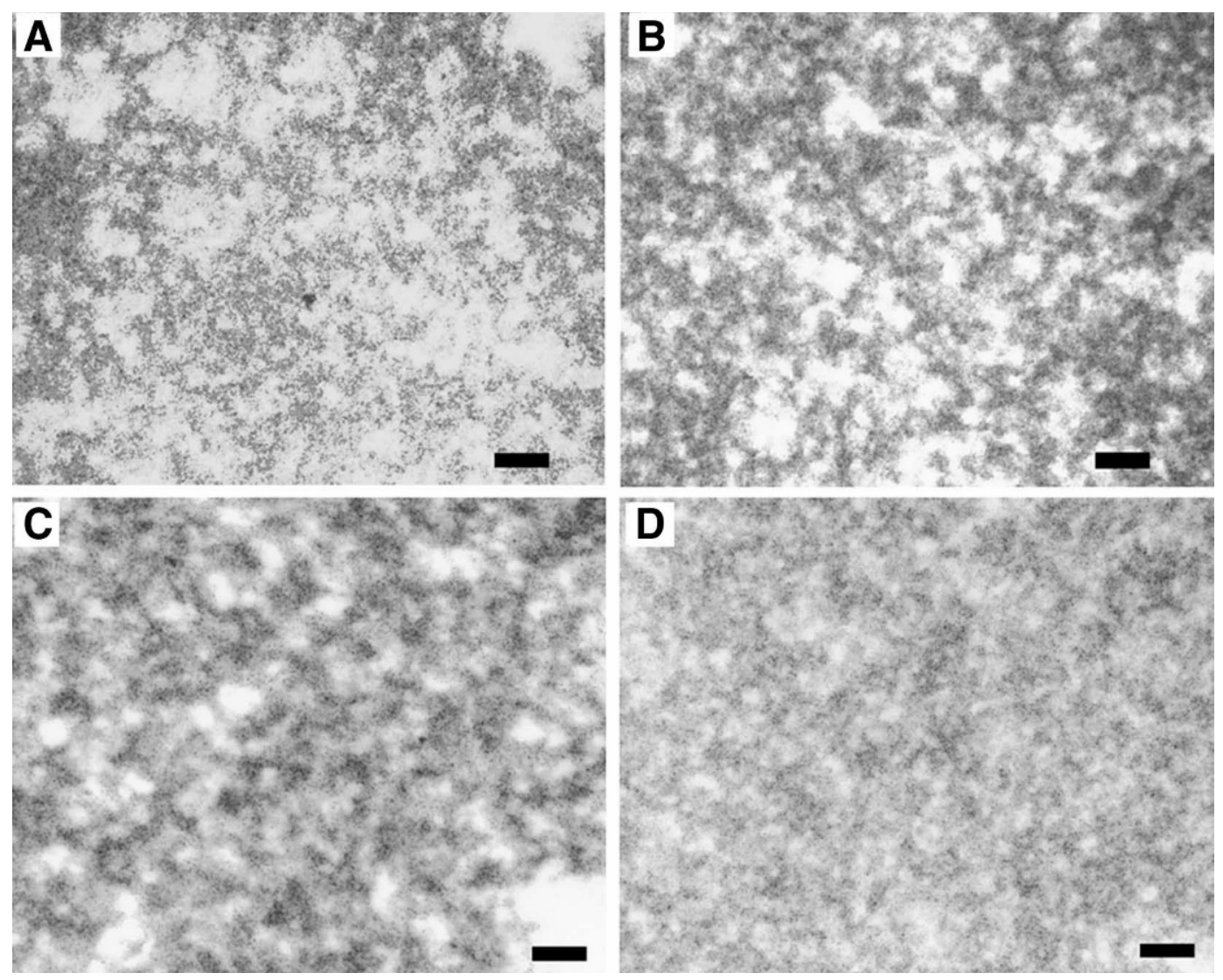

Figure 6. High magnification transmission electron micrographs of pH 5.8 cheeses HPH1 (A) and HPH3 (B), and pH 5.3 cheeses LPH1 (C) and LPH3 (D); these cheeses contained $0.6 \%$ calcium (A, B, and C) or $0.3 \%$ calcium (D). Bar $=100 \mathrm{~nm}$.

pockets, even though moisture levels were typically 2 to $3 \%$ higher in the low calcium cheeses compared to their higher calcium counterparts. Reduction in calcium, and subsequent reduction in protein-protein interactions, apparently increased protein hydration and more whey remained entrapped within the protein matrix. Similar observations were made in the studies of Guinee et al. (2002) and Joshi et al. (2004d), in which reducing calcium content of Mozzarella cheese led to a more hydrated protein matrix.

Because a large quantity of the moisture exists outside the protein matrix (i.e., in serum pockets), it can be said that in any given volume of cheese, the protein density was higher and more compact in the $0.6 \%$ calcium cheeses than in the $0.3 \%$ calcium cheeses. This increased protein density leads to a more rigid structure, increased hardness, and decreased melt. In a similar fashion, injecting calcium chloride directly into cheese causes the protein fibers in the cheese matrix to contract and expel more whey (Pastorino et al., 2003a).

Interaction of calcium with casein molecules within the protein matrix occurs as the positively charged calcium ions associate with negatively charged regions of the caseins. This can lead to neutralization of charge repulsion between the caseins, and, because of calcium's divalent nature, can contribute to bridging between proteins and a stronger, more cross-linked, protein matrix (Pastorino et al., 2003a). In contrast, monovalent ions such as sodium have a slight salting-in effect at low concentrations making the proteins more soluble (Paulson et al., 1998), and a salting-out effect at high concentrations making them less soluble (Guinee and Fox, 2004). Thus, protein cross-linking via calcium is more important than charge neutralization when considering protein interactions and their effects on cheese functionality. Although electrostatic interactions (and hydrogen bonding) between proteins take place within the cheese matrix, these are independent of calcium crosslinking, and only when the cheese matrix is depleted of calcium are the proteins released from each other (Gagnaire et al., 2002).

Furthermore, in agreement with Pastorino et al. (2003b), at cheese $\mathrm{pH}>5.0$, the effect of $\mathrm{pH}$ on cheese is related to its influence on residual calcium content in the cheese. Typically, a higher $\mathrm{pH}$ cheese has higher calcium content than a lower $\mathrm{pH}$ cheese (e.g., HPH1 

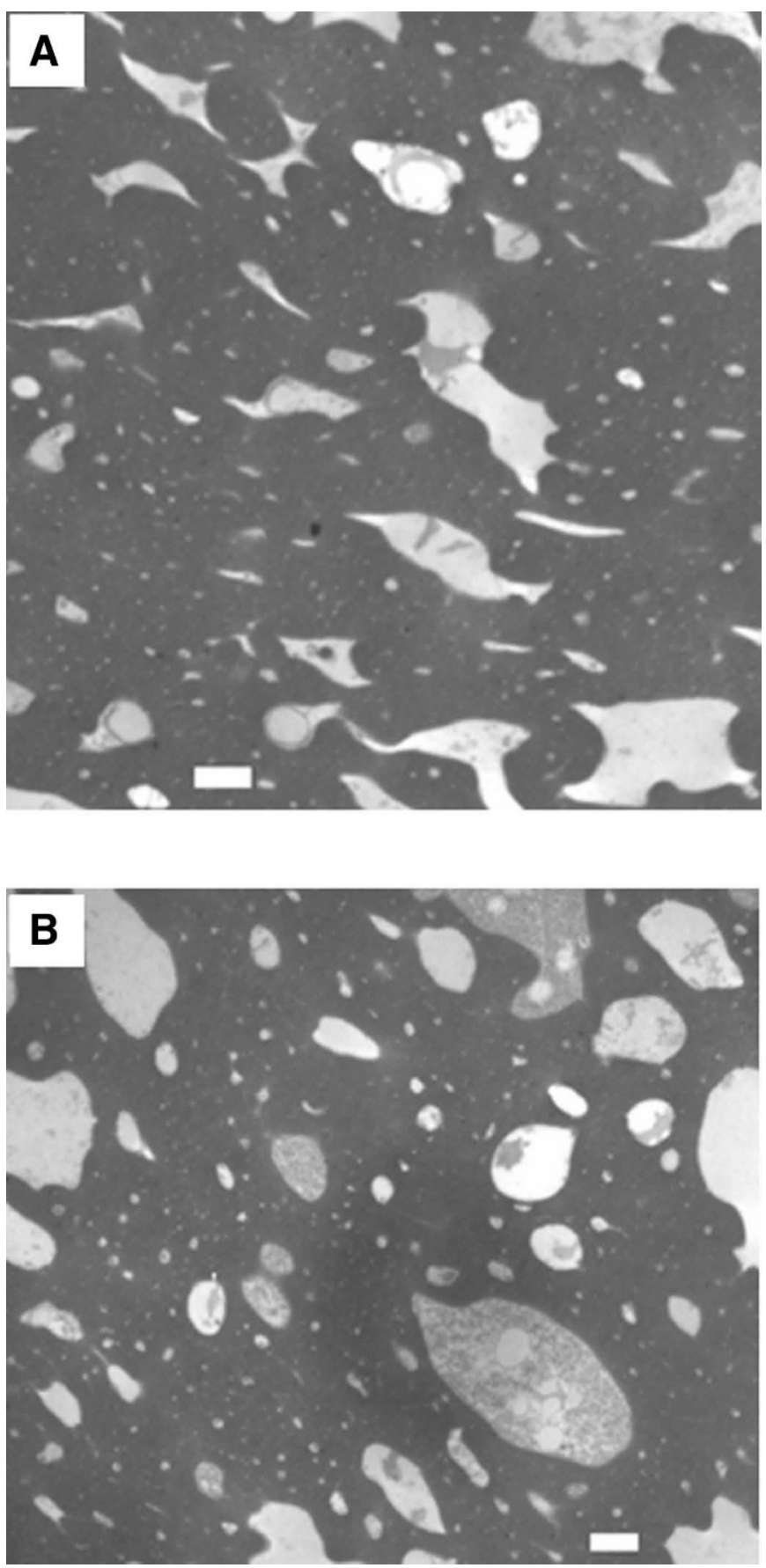

Figure 7. Transmission electron micrographs of $\mathrm{pH} 5.3$ cheeses LPH1 (A) and LPH2 (B) made using a short and long dry-stirring time, respectively. Bar $=1 \mu \mathrm{m}$.

and HPH2 compared with LPH3 and LPH4). But if calcium is maintained at the same level as the higher $\mathrm{pH}$ cheeses, the cheeses had similar structural and functional characteristics independent of their $\mathrm{pH}$. Thus, it appears that the calcium-controlling effect on cheese performance extends at least over the $\mathrm{pH}$ range of 5.0 to 5.8 .

We had anticipated from preliminary work that by acidifying milk to $\mathrm{pH} 5.8$ with a combination of acetic acid and citric acid, and by adding EDTA as a calciumchelator into the whey, cheeses HPH3 and HPH4 would have levels of calcium comparable to the $\mathrm{pH} 5.3$ cheeses, LPH1 and LPH2. However, this was not the case and HPH3 and HPH4 cheeses had calcium contents of $0.6 \%$ and similar structural and functional characteristics as HPH1 and HPH2.

Moisture will migrate into or out of the protein matrix based on the chemical environment surrounding the proteins and the temperature of the cheese (Pastorino et al., 2002). The direction of serum movement depends on whether the free energy of the total system (protein plus surrounding aqueous phase) can be lowered by the proteins becoming more or less hydrated. Thus, in cheeses with high calcium content, the system favors low protein hydration (with increased protein-protein interactions) and the proteins exist as densely compacted protein bundles with less moisture contained within the protein matrix, and considerable moisture being present in the cheese as free serum pockets. As calcium is decreased in the cheese matrix, protein-protein interactions within the cheese matrix are decreased and protein-water interactions are increased. Thus, it becomes more thermodynamically favorable for water to diffuse into the protein matrix, and the overall protein matrix becomes more hydrated, as observed in this work and that of others (Guinee et al., 2002; Joshi et al., 2004d).

This implies that when Mozzarella cheese curd with normal calcium content (i.e., $\geq 0.6 \%$ calcium) is salted and stretched immediately after whey drainage, curd shrinkage and whey expulsion is interrupted, but it could be expected that further syneresis would occur during storage of such cheese. Similar observations were made by Merrill et al. (1994) during their development of a procedure for manufacturing a reduced-fat Mozzarella cheese. Successfully increasing the moisture content of cheese (so that it is not expelled during storage) requires a chemical intervention that increases the water-holding capacity of the cheese matrix rather than a physical intervention such as shortening the manufacturing time. An example of such a chemical intervention would be to lower the calcium content of the cheese so the proteins that comprise the cheese matrix become more hydrated, as shown by the LPH3 and LPH4 cheeses in this study and our previous observations (Paulson et al., 1998). Because of this, the LPH3 and LPH4 cheeses had moisture contents above that which was planned. 


\section{Cheese Functionality}

The differences in protein structure between cheeses with $0.6 \%$ calcium and cheeses with $0.3 \%$ calcium explain the differences in melt, hardness, and adhesiveness of the cheese. An increase in protein density and cross linkages through the interactions of the calcium ions would lead to increased structural rigidity of the cheese matrix and overall increased cheese hardness. Indeed, in this study as in others (Pastorino et al., 2003a; Joshi et al., 2004b; Sheehan and Guinee, 2004), cheeses with higher calcium were firmer than cheeses with lower calcium.

Similarly, this structural rigidity explains the decreased melt performance of the higher calcium cheeses (Guinee et al., 2002; Joshi et al., 2004c,d; Sheehan and Guinee, 2004). As protein-protein interactions within the cheese matrix increase, more energy is required to disrupt the bonds within the cheese matrix and allow the proteins to flow past one another.

In a pizza oven supplying constant heat over a set period, cheeses with increased protein-protein interactions would be expected to take longer to melt as energy is absorbed to melt the cheese. If too much moisture is lost from the cheese surface before sufficient heat is absorbed to melt the cheese and begin to flow, melt can be reduced. In the low-calcium cheeses, with highly hydrated protein matrices and fewer protein interactions, the bonds between proteins are much weaker and require less energy to break. As a result, the cheese will melt rapidly and thus avoid the problem of protein dehydration on the cheese surface that is detrimental to the melting of nonfat cheeses in a forced-air oven (Rudan and Barbano, 1998).

Adhesiveness of the proteins in the low-calcium cheeses was increased compared with cheeses with $0.6 \%$ calcium. Again, this can be explained by the protein structure of the cheese matrix. In high-calcium cheese, the proteins are highly aggregated and there is more moisture present in serum pockets. Thus, when cut, the proteins maintain their self-association and have low adhesiveness. In contrast, when calcium is reduced, the proteins are more unfolded and available to interact with other surfaces. We previously observed (Paulson et al., 1998) that when hand stretching directly acidified, nonfat Mozzarella cheese with low calcium content, these cheeses had highly hydrated matrices and the cheeses were sticky and adhered readily to rubber gloves. Presumably, the unfolding of the protein aggregates in the low calcium environment exposes more hydrophobic sites and charged sites as well as imparting a greater degree of flexibility, thus allowing the proteins to readily interact with surfaces such as rubber or steel. As moisture increased in the low-cal- cium cheeses, adhesiveness increased, indicating a progressive weakening of the matrix with increased water content. In the higher calcium cheeses, with compact bundles of proteins, the charged regions of the protein matrix are tightly associated with each other and are less available for external interactions.

\section{CONCLUSIONS}

Reducing the calcium content to $0.3 \%$ in directly acidified Mozzarella cheese led to increased cheese melt, a softer body, and a homogeneous microstructure throughout the cheese. These changes occurred independently of $\mathrm{pH}$ ( $\mathrm{pH} 5.3 \mathrm{vs}$. $\mathrm{pH}$ 5.8) or moisture content (approximately 66 to $70 \%$ ) of the nonfat cheese. When calcium content of the different $\mathrm{pH}$ cheese was retained at $0.6 \%$, the cheeses had similar functional performance. This confirms observations that at $\mathrm{pH}>5.0$, it is calcium content that controls cheese functionality, and that the influence of cheese $\mathrm{pH}$ is related to its effect on calcium solubilization (and loss into the whey) during cheesemaking. Such differences in cheese functionality can be explained by differences in the microstructure of the cheese matrix. As calcium content is increased, the protein bundles become larger and denser with a corresponding increased in serum pockets as water is excluded from the protein network matrix. Reducing calcium increases hydration of the protein matrix and weakens protein interactions, resulting in softening of the cheese and improved molten flow as cheese is heated.

\section{ACKNOWLEDGMENTS}

The authors gratefully acknowledge the technical assistance of William McManus for electron microscopy, and Donald Sisson for statistical analysis. Funding for the research was provided by Dairy Management Inc. (Rosemont, IL) This paper is approved as Contribution number 7699 of the Utah Agricultural Experiment Station, Utah State University (Logan).

\section{REFERENCES}

AOAC. 1990. Official Methods of Analysis. 15th ed. Association of Official Analytical Chemists Arlington, VA.

Breene, W. M., W. V. Price, and C. A. Ernstrom. 1964. Changes in composition of Cheddar cheese curd during manufacture as a guide to cheese making by direct acidification. J. Dairy Sci. 47:840-848.

Gagnaire, V., E. Trotel, Y. le Graet, and J. Leonil. 2002. Role of electrostatic interactions in the curd of Emmental cheese. Int. Dairy J. 12:601-608.

Ge, Q., M. Almena-Aliste, and P. S. Kindstedt. 2002. Reversibility of $\mathrm{pH}$-induced changes in the calcium distribution and melting characteristics of Mozzarella cheese. Aust. J. Dairy Technol. $57: 3-9$. 
Guinee, T. P., E. P. Feeney, M. A. E. Auty, and P. F. Fox. 2002. Effect of $\mathrm{pH}$ and calcium concentration on some textural and functional properties of Mozzarella cheese. J. Dairy Sci. 85:1655-1669.

Guinee, T. P., and P. F. Fox. 2004. Page 224 in Cheese Chemistry, Physics and Microbiology. Vol. 1., 3rd ed. P. F. Fox, P. L. H. McSweeney, T. M. Cogan, and T. P. Guinee, ed. Elsevier, London, UK.

Joshi, N. S., K. Muthukumarappan, and R. I. Dave. 2003. Understanding the role of calcium in functionality of part skim Mozzarella cheese. J. Dairy Sci. 86:1918-1926.

Joshi, N. S., K. Muthukumarappan, and R. I. Dave. 2004a. Effects of reduced-calcium, test temperature and storage on stretchability of part-skim Mozzarella cheese. Aust. J. Dairy Technol. 59:60-65.

Joshi, N. S., K. Muthukumarappan, and R. I. Dave. 2004b. Viscoelastic properties of part skim Mozzarella cheese: Effect of calcium, storage, and test temperature. Int. J. Food Prop. 7:239-252.

Joshi, N. S., K. Muthukumarappan, and R. I. Dave. 2004c. Modeling rheological characteristics and calcium content of Mozzarella cheese. J. Food Sci. 69:FEP97-FEP101.

Joshi, N. S., K. Muthukumarappan, and R. I. Dave. 2004d. Effect of calcium on microstructure and meltability of part skim Mozzarella cheese. J. Dairy Sci. 87:1975-1985.

Konstance, R. P., and V. H. Holsinger. 1992. Development of rheological test method for cheese. Food Technol. 1:105-109.

McMahon, D. J., R. L. Fife, and C. J. Oberg. 1999. Water partitioning in Mozzarella cheese and its relationship to cheese meltability. J. Dairy Sci. 82:1361-1369.

McManus, W. R., D. J. McMahon, and C. J. Oberg. 1993. High resolution scanning electron microscopy of milk products: A new sample preparation procedure. Food Struct. 12:475-482.

Merrill, R. K., C. J. Oberg, and D. J. McMahon. 1994. Mozzarella cheese: A method for manufacturing reduced fat Mozzarella cheese. J. Dairy Sci. 77:1783-1789.
Mistry, V. V., and D. L. Anderson. 1993. Composition and microstructure of commercial full fat and low fat cheeses. Food Struct. 12:259-266.

Oberg, C. J., W. R. McManus, and D. J. McMahon. 1993. Microstructure of Mozzarella cheese during manufacture. Food Struct. $12: 251-258$

Pastorino, A. J., R. I. Dave, C. J. Oberg, and D. J. McMahon. 2002. Temperature effect on structure-opacity relationships of nonfat Mozzarella cheese. J. Dairy Sci. 85:2106-2113.

Pastorino, A. J., C. L. Hansen, and D. J. McMahon. 2003b. Effect of $\mathrm{pH}$ on the chemical composition and structure function relationships of cheddar cheese. J. Dairy Sci. 86:2751-2760.

Pastorino, A. J., N. P. Ricks, C. L. Hansen, and D. J. McMahon. 2003a. Effect of calcium and water injection on structure-function relationships of cheese. J. Dairy Sci. 86:105-113.

Paulson, B. M., D. J. McMahon, and C. J. Oberg. 1998. Influence of salt on appearance, functionality, and protein arrangements in nonfat Mozzarella cheese. J. Dairy Sci. 81:2053-2064.

Rudan, M. A., and D. M. Barbano. 1998. A model of Mozzarella cheese melting and browning during pizza baking. J. Dairy Sci. 81:2312-2319.

Sheehan, J. J., and T. P. Guinee. 2004. Effect of $\mathrm{pH}$ and calcium level on the biochemical, textural and functional properties of reducedfat Mozzarella cheese. Int. Dairy J. 14:161-172.

Tunick, M. H., K. L. Mackey, J. J. Shields, P. W. Smith, P. Cooke, and E. L. Malin. 1993. Rheology and microstructure of low fat Mozzarella cheese. Int. Dairy J. 3:649-662.

US Department of Agriculture. 1980. USDA specifications for Mozzarella cheeses. Agric. Marketing Service, USDA, Washington, DC

US Environmental Protection Agency (EPA). 1992. Inductively coupled plasma-atomic emission spectroscopy. Method 6010a (Revision 1) in Test Methods for Evaluating Solid Waste, Vol. 1A: Laboratory Manual Physical/Chemical Methods. Office of Solid Waste and Emergency Response, US EPA, Washington, DC.

van Vliet, T. 1991. Terminology to be used in cheese rheology. Pages $5-15$ in Rheological and Fracture Properties of Cheese. IDF Bulletin No. 268. Int. Dairy Fed., Brussels, Belgium. 